\title{
МНОГОЛЕТНИЙ АНАЛИЗ ОСОБЕННОСТЕЙ УЧЕТА НЕСЧАСТНЫХ СЛУЧАЕВ НА ПРОИЗВОДСТВЕ В РОССИИ
}

\author{
ГАЛИНА ТИХОНОВА, АНАСТАСИЯ ЧУРАНОВА
}

\begin{abstract}
Класс внешних причин - один из ведущих в формировании сверхсмертности мужчин трудоспособного возраста. В России велико количество травмоопасных отраслей и число погибших на производстве в результате несчастных случаев. При изучении производственного травматизма (ПТ) выделяют травматизм общий и со смертельным исходом.
\end{abstract}

\begin{abstract}
Несколько десятилетий наблюдается устойчивое снижение частоты производственных травм при ухудшающихся условиях труда. В 2016 г. коэффициент ПТ составил в России 1,3 на 1000 работников, а в старых странах Европь - 7,2-34,6\%о. Исходя из опыта развитых стран, для оченки вероятного общего числа пострадавших на производстве в странах с плохим учетом Международная организачия труда рекомендует использовать отномение общего числа травм к 1 случаю гибели, равное 500-1000:1. Возможность использования данной характеристики для России подтвердил исторический анализ. Приближенное $\kappa$ современным показателям в Европе отношение регистрировалось в России в 1904-1930 г2. В 2016 г. оно составляло лишь 21:1. При рекомендуемом показателе число пострадавших на производстве в России могло составить 1,0-2,1 млн по сравнению с 39,9 тыс. официально зарегистрированных.

В Плане мероприятий по реализации третьего этапа Концеепии демографической политики в РФ предусмотрено сокращение смертности в трудоспособном возрасте за счет улучшения условий и охраны труда, включающего внедрение новой системы управления охраной труда, основанной на оценке профессиональных рисков. ПТ - один из двух официальных статистических показателей состояния здоровья работающих. Массовое сокрытие несчастных случаев препятствует формированию адекватной информационной базы и принятию обоснованных управленческих ремений.
\end{abstract}

Ключевые слова: внешние причины смерти, производственный травматизм.

\section{ВВЕДЕНИЕ}

С 2005 г. в России наблюдается положительная динамика смертности, однако в трудоспособном возрасте ее уровень остается неприемлемо высоким, особенно у мужского населения. Одной из ведущих причин сверхсмертности являются внешние причины смерти, которые в трудоспособном возрасте занимают второе место у мужчин $(27,8 \%)$ и третье у женщин (19,7\%). Стандартизованные коэффициенты смертности от этого класса причин в возрасте 15-59(54) лет в России приблизительно в 4 раза выше, чем в странах ЕС-28 (Россия-2015 г. и ЕС-28-2013 г. - в 4,2 раза у мужчин и в 3,6 раза у женщин) (Тихонова, Горчакова 2018: 46).

ГАЛИНА ИЛЬИНИЧНА ТИХОНОВА (gtikhonova@yandex.ru), ФЕДЕРАЛЬНОЕ ГОСУДАРСТВЕННОЕ БЮДЖЕТНОЕ НАУЧНОЕ УЧРЕЖДЕНИЕ «НАУЧНО-ИССЛЕДОВАТЕЛЬСКИЙ ИНСТИТУТ МЕДИЦИНЫ ТРУДА ИМЕНИ АКАДЕМИКА Н.Ф. ИЗМЕРОВА», РОССИЯ.

АНАСТАСИЯ НИКОЛАЕВНА ЧУРАНОВА (nastja_3006@mail.ru), ФЕДЕРАЛЬНОЕ ГОСУДАРСТВЕННОЕ БЮДЖЕТНОЕ НАУЧНОЕ УЧРЕЖДЕНИЕ «НАУЧНО-ИССЛЕДОВАТЕЛЬСКИЙ ИНСТИТУТ МЕДИЦИНЫ ТРУДА ИМЕНИ АКАДЕМИКА Н.Ф. ИЗМЕРОВА», РОССИЯ.

СТАТЬЯ ПОСТУПИЛА В РЕДАКЦИЮ В ФЕВРАЛЕ 2019 Г. 
Всего в России в 2016 г. из-за травм, отравлений и других внешних причин погибло 167,5 тыс. человек, из них почти 70\% (114,8 тыс.) в трудоспособном возрасте (Росстат 2017). Инвалидами стали 25,5 тыс. человек (Основные показатели... 2016). Ущерб продолжительности жизни, наносимый внешними причинами смерти, определяется не только высокой долей смертей от этого класса причин, но и значительно более молодым средним возрастом смерти по сравнению с другими ведущими классами, что определят повышенное внимание к этой проблеме.

В недавно опубликованном масштабном исследовании смертности от внешних причин в России (Вишневский 2017) проведен разносторонний анализ этой проблемы. Наряду с рассмотрением смертности от внешних причин в контексте этапов эпидемиологических переходов, подробно проанализированы ее половые и возрастные аспекты. В соответствии с МКБ-Х несчастные случаи и намеренные повреждения подробно обсуждены в подгруппах причин: транспортные несчастные случаи и несчастные случаи вследствие случайных отравлений алкоголем, падений, утопления, воздействия огня и высоких температур и др., а также происшествия со смертельным исходом в результате самоповреждения или нападений и др. Смертность от внешних причин также проанализирована с учетом социально-экономических, этнорелигиозных, поведенческих и иных факторов.

Вместе с тем при изучении класса травм и отравлений как одной из ведущих причин низкой продолжительности жизни и высокого уровня смертности и инвалидизации в трудоспособном возрасте важно выделять производственный травматизм, т. е. причины и особенности несчастных случаев, которые происходят на рабочем месте. Это связано с тем, что пути их профилактики, а также оплата ущерба и затрат на реабилитацию происходят иначе, чем при бытовых несчастных случаях.

Предупреждение несчастных случаев на рабочем месте и экономическая ответственность в случае их возникновения (реабилитация, инвалидность, пенсии членам семьи в случае гибели кормильца и др.) лежит на бизнесе, а лечение непроизводственных травм и оплата их отдаленных последствий осуществляется за счет средств налогоплательщиков.

Подчеркнем, что анализ производственного травматизма особенно важен для России, учитывая структуру производства, в которой высока доля травмоопасных отраслей: добыча полезных ископаемых, сельское хозяйство, строительство, транспорт и др. Так, например, в 2016 г. частота производственного травматизма со смертельным исходом на предприятиях по добыче полезных ископаемых была выше среднероссийского показателя в 2,7 раза, в строительстве - в 2,9 раза, в сельском хозяйстве - в 1,7 раза и т.д. (Социальное положение... 2017: 85).

Значимость этой проблемы отмечена в документе, посвященном III этапу реализации Концепции демографической политики (утверждена распоряжением Правительства РФ от 14 апреля 2016 г. №669-р) с 2016 по 2020 г., где особо выделен комплекс мероприятий, направленных на снижение смертности от предотвратимых причин и снижения смертности за счёт улучшения условий и охраны труда. 
В России в последние годы по данным Фонда социального страхования (ФСС) регистрируется 40-50 тыс. случаев производственных травм в год (Министерство труда...2017), из них около 2 тыс. пострадавших становятся инвалидами вследствие трудового увечья (Основные показатели... 2016) и более 2 тыс. погибают (Министерство труда...2017). Экономические потери, связанные с компенсациями по несчастным случаям и профессиональным заболеваниям, обусловленным состоянием условий и охраны труда на предприятиях страны в 2016 г., составили 1,53 трлн. рублей или 1,8\% ВВП (Министерство труда...2017). Для мировой экономики потери «по причине проблем здоровья, связанных с работой» оцениваются в 4\% ВВП (ГТПДТ и Бюро МОТ... 2010).

На совещании «О снижении производственного травматизма», состоявшемся 12 декабря 2017 в Москве, премьер-министр Д.А. Медведев отметил, что за 10 лет в России несчастных случаев на производстве стало в два раза меньше ${ }^{1}$. Он также указал на необходимость продолжения работы по дальнейшему снижению производственного травматизма.

\section{МАТЕРИАЛЫ И МЕТОДЫ}

В России несчастным случаем на производстве считается событие, произошедшее с работником, участвующим в трудовой деятельности при исполнении им должностных обязанностей или иной работы по поручению работодателя, в результате которого работником были получены травмы, повлекшие за собой временную (сроком на один рабочий день и более) или стойкую утрату им трудоспособности либо смерть (ст. 227 Трудового кодекса Российской Федерации). По степени тяжести повреждения здоровья несчастные случаи квалифицируются как легкие, тяжелые, со смертельным исходом.

В соответствии с действующим законодательством расследование легкого несчастного случая на производстве работодатель проводит самостоятельно. Расследование тяжелых несчастных случаев, групповых и со смертельным исходом проводится при участии контролирующих органов (Инспекция по труду, прокуратура, профсоюзы, ФСС и др.).

Следует отметить, что несчастные случаи на производстве с работниками, не имеющими официального трудоустройства (работающие нелегально), как правило, не расследуются и не регистрируются. Исключение составляют происшествия, расследованные по жалобе потерпевшего или его родственников при установлении факта трудовых отношений в судебном порядке.

Анализ состояния производственного травматизма в России, а также данных об учете и регистрации несчастных случаев на производстве в разные периоды социальноэкономического развития страны проводился на основе материалов официальных статистических изданий:

\footnotetext{
${ }^{1}$ Сайт Правительства России: URL: http://government.ru/news/30553/ (дата обращения 20.05.2018).
} 
- 1877-1914 гг. - (Сборник статистических сведений... 1888; 1893; 1899; 1903; 1906; 1908; 1910; Свод отчетов... 1903; 1904; 1907;1909; 1910; 1915);

- 1914-1917 гг. - данные Центрального статистического комитета по отдельным страховым товариществам (Статистический сборник... 1922);

- 1927-1933 гг. - данные органов социального страхования о травматизме застрахованного населения (Статистический справочник СССР .. 1929; СССР в цифрах... 1935);

- 1965-1989 гг. - данные Госкомстата СССР (Иванова 2011; Труд в СССР... 1989; Социальное развитие...1991);

- 1990-2017 гг. - данные Росстата (до 2005 г. - Госкомстат), ФСС России, Федеральной службы по труду и занятости России (Роструд) (Социальное положение... 2001; 2004; 2008; 2011; 2017; Министерство труда... 2017).

Цели и методы сбора информации у Росстата, ФСС и Роструда различные, поэтому статистическая информация, предоставляемая ими, также различается.

ФС осуществляет сбор данных по пострадавшим работникам, застрахованным по обязательному социальному страхованию от несчастных случаев на производстве и профессиональных заболеваний. Фонд проводит экспертизу полученных материалов расследования несчастных случаев и выносит заключение, являются ли они страховыми. База данных ФСС содержит информацию только о страховых случаях.

Роструд производит сбор и анализ данных о пострадавших на производстве по всем предприятиям, но только по групповым несчастным случаям и случаям с тяжелым и смертельным исходом.

Росстат производит сбор и анализ данных о пострадавших и погибших работниках при всех видах несчастных случаев на производстве на крупных и средних предприятиях сплошным методом, на малых - выборочным в 12 видах экономической деятельности (ВЭД). Не находятся под наблюдением Росстата 5 ВЭД: финансовая, государственное управление и обеспечение военной безопасности, социальное страхование, образование, деятельность домашних хозяйств и экстерриториальных организаций. Из всей среднесписочной численности работников Росстат охватывает наблюдением около половины.

Для оценки полноты учета производственного травматизма в России была использована методика Международной организации труда (MOT) по оценке достоверности статистики несчастных случаев на производстве в странах с несовершенным учетом, основанная на положении, что травматизм со смертельным исходом регистрируется лучше, чем остальные травмы, поэтому несчастные случаи со смертельным исходом являются базой для расчета вероятного общего числа пострадавших на производстве (Hämäläinen, Saarela, Takala 2009). Переход от числа погибших работников к общему числу пострадавших на производстве осуществляется с помощью отношения, основанного на многолетнем опыте развитых стран и показывающего, какое количество травм в среднем приходится на один случай гибели на производстве. Это соотношение для 
каждой из стран достаточно устойчиво и составляет в среднем по ЕС от 500 до 1000 травм на 1 случай гибели на производстве.

\section{СОВРЕМЕННОЕ СОСТОЯНИЕ ПРОИЗВОДСТВЕННОГО ТРАВМАТИЗМА ПО ОФИЦИАЛЬНЫМ ДАННЫМ В РОССИИ И ЗА РУБЕЖОМ}

Анализ динамики общего производственного травматизма (все виды травм: легкие, тяжелые и со смертельным исходом), выполненный на основе данных Росстата за почти тридцатилетний период свидетельствовал, что официально регистрируемые показатели с 1990 по 2017 г. сократились в 6,4 раза (с 8,4 до 1,3 на 1000 работников; рисунок 1А). Уровень производственного травматизма со смертельным исходом в рассматриваемый период также снижался, однако, более медленными темпами. Коэффициент снизился с 0,129 до 0,056 на 1000 работников, т. е. в 2,3 раза (рисунок 1Б).

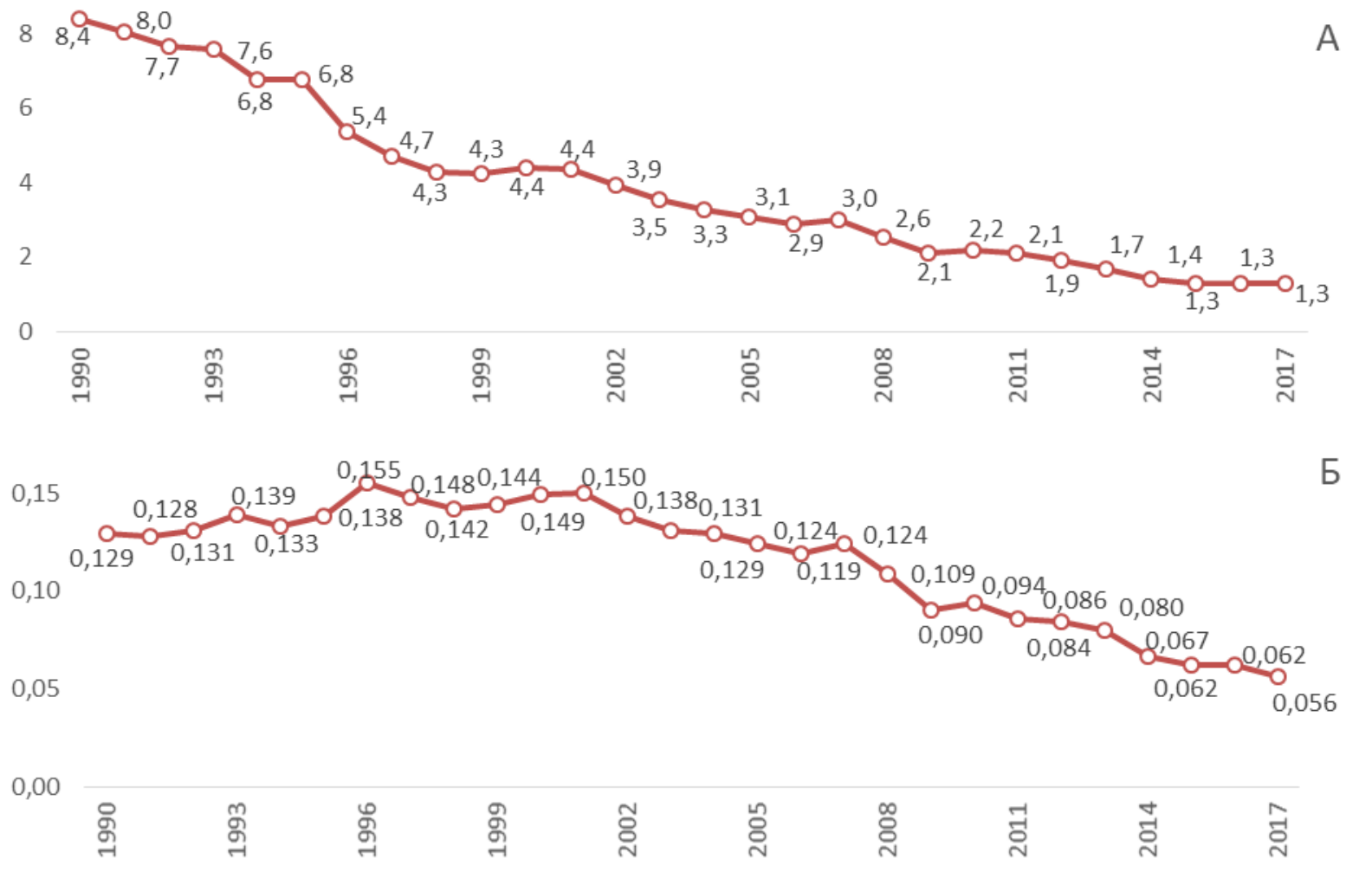

\section{Рисунок 1. Коэффициенты общего производственного травматизма (А) и травматизма со смертельным исходом (Б) в России в 1990-2017 гг., на 1000 работников}

Источники: (Социальное положение... 2001; 2004; 2008; 2011; 2017).

Частично снижение показателей травматизма можно объяснить реструктуризацией экономики в 90-е годы и сокращением числа занятых в производственных, наиболее травмоопасных, видах экономической деятельности.

С другой стороны, уровень производственного травматизма напрямую зависит от состояния условий труда на предприятиях и состояния охраны труда и техники безопасности. В 1990-х годах в условиях социально-экономических реформ на многих 
предприятиях перестала осуществляться модернизация основных производственных фондов, в результате чего их физический износ достиг 50-70\% и даже 90\%, параллельно происходило разрушение целостной системы охраны труда, организованной в СССР. Возросла доля предприятий, условия труда на которых не соответствовали санитарногигиеническим нормативам, постоянно увеличивался удельный вес работников, занятых во вредных и опасных условиях труда, на тяжелых работах.

Так, в 2016 г., по данным Роспотребнадзора, к опасным и неблагоприятным для здоровья работающих относилось около 74\% обследованных предприятий (Роспотребнадзор 2017). За период 2004-2017 гг. удельный вес работников, занятых в условиях труда, не отвечающих санитарно-гигиеническим нормативам, вырос в 1,7 раза (рисунок 2).

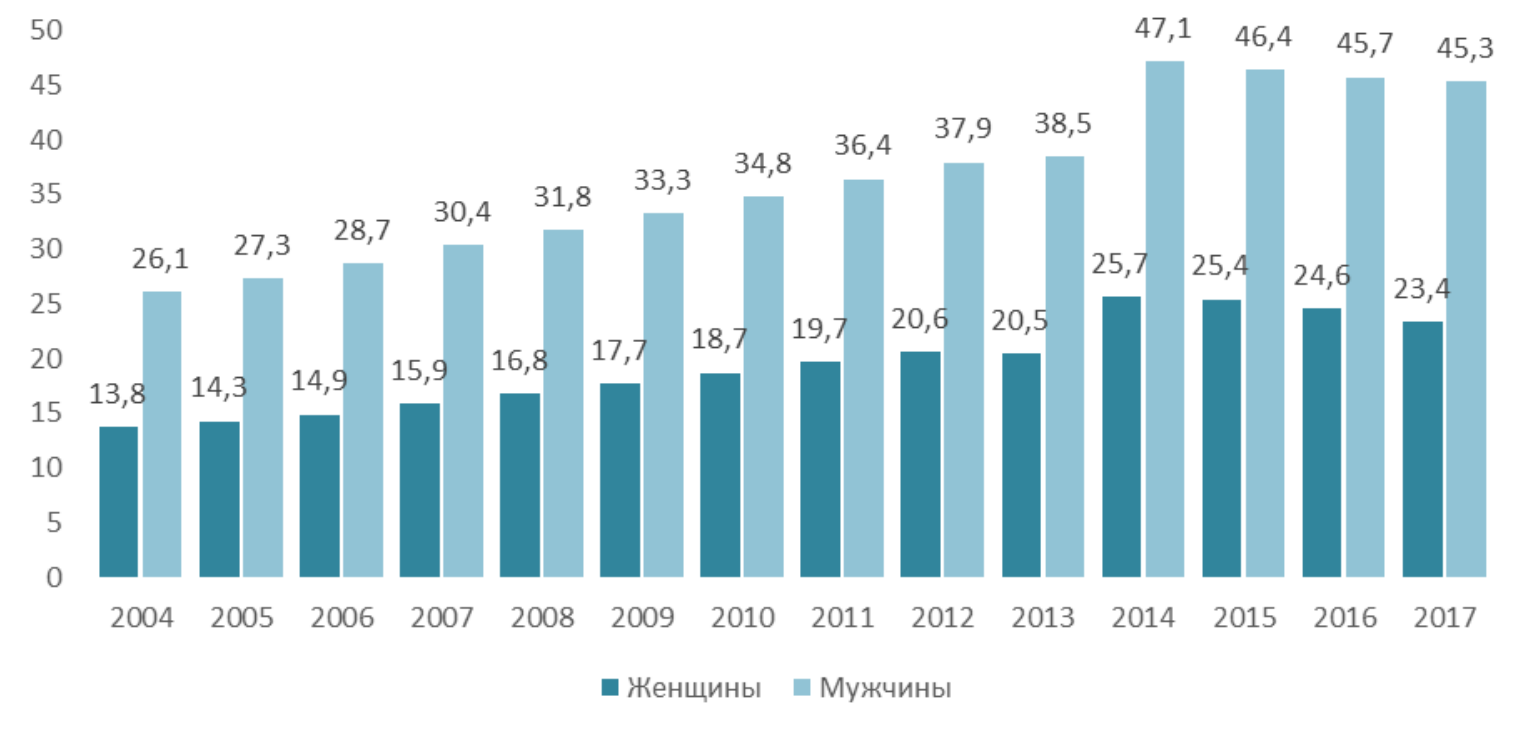

\section{Рисунок 2. Доля мужчин и женщин, занятых во вредных и опасных условиях труда в России в 2004-2017 гг., \%}

Источники: (Социальное положение... 2008; 2011; 2017).

Отметим, что начиная с 2015 г. происходит снижение показателя доли работников, занятых на рабочих местах, не соответствующих санитарно-гигиеническим нормативам. Однако, по мнению экспертов, этот процесс связан с изменением методических подходов к оценке условий труда (Евстигнеева 2016). В 2014 г. вместо процедуры аттестации рабочих мест в соответствии с Федеральным законом от 28.12.13 №426-Ф3 "О специальной оценке условий труда" была внедрена система специальной оценки условий труда (СОУТ). Изменение нормативов по ряду производственных факторов в сторону их снижения или исключения из оценки способствует переводу многих рабочих мест, условия труда на которых ранее относились к вредным и/или опасным, в категорию допустимых. Приведенные данные позволяют полагать, что последовательное снижение показателя доли рабочих мест, не соответствующих санитарно-гигиеническим нормативам в России в 2015 2017 гг., обусловлено преимущественно внедрением СОУТ, а не реальным улучшением условий и охраны труда. 
Возвращаясь к производственному травматизму, следует признать, что снижение официально регистрируемых показателей частоты несчастных случаев на фоне чрезвычайно высокой доли предприятий, признанных опасными и неблагоприятными для здоровья работников, представляется неправдоподобным.

Ряд отечественных и зарубежных экспертов объясняют оптимистичную динамику показателей производственного травматизма в России массовым сокрытием легких производственных травм и регистрацией их в качестве «бытовых» (Кузнецов 2005; Русак 2006; Волков 2006; Измеров и др. 2013)². В соответствии с действующим законодательством пострадавшему на производстве работнику первую доврачебную помощь должны оказать на предприятии, а затем доставить в медучреждение транспортом работодателя или вызвать скорую помощь (ст. 228 ТК РФ).

Как правило, не заинтересованный в регистрации производственной травмы работодатель договаривается с пострадавшим работником о том, что при поступлении в медучреждение он сообщит, что травма произошла в быту. Таким образом, факт происшествия на предприятии нигде не фиксируется, расследование не проводится. Такая практика широко распространена при легких производственных травмах. Данные об увеличении длительности больничного листа по производственной травме в расчете на одного пострадавшего подтверждают это. Средняя длительность одного случая нетрудоспособности выросла в 2,1 раза с 23,4 дня в 1990 г. до 49,0 дней в 2016 г., что свидетельствует о регистрации преимущественно тяжелых травм, больничный лист по которым составляет около 50 дней (Социальное положение... 2008; 2011; 2017).

О сокрытии травм может свидетельствовать сравнительный анализ абсолютных данных о числе несчастных случаев на производстве в зарубежных странах и России. Так, в 2016 г. в Германии из 40,1 млн работников предприятий (Vollarbeiter) ${ }^{3}$ пострадали на производстве 877,1 тыс., во Франции из 18,5 млн наемных работников (salariés) ${ }^{4}$ были травмированы в результате несчастных случаев на производстве 626,2 тыс. и, наконец, в Финляндии при 2,4 млн занятых (employments) ${ }^{5}$ было зарегистрировано 109,4 тыс. пострадавших на производстве ${ }^{6}$. Это в 2,5 раза больше, чем в России, где в том же 2016 г. при среднесписочной численности работников 44,4 млн человек по данным ФСС было зарегистрировано всего 39,8 тыс. производственных травм (Труд и занятость... 2017; Министерство труда...2017). Особо отметим, что абсолютные числа пострадавших на

\footnotetext{
${ }^{2}$ Хусберг В. (2006, 7 ноября). В России просто не регистрируются все несчастные случаи. Приложение к газете «Коммерсант». URL: https://www.kommersant.ru/doc/718902

${ }^{3}$ Сайт German Social Accident Insurance (DGUV): URL: https://www.dguv.de/de/zahlen-fakten/au-wugeschehen/index.jsp (дата обращения: 04.04.2019).

${ }^{4}$ Direction des risques professionnels:

URL:http://www.risquesprofessionnels.ameli.fr/fileadmin/user_upload/document_PDF_a_telecharger/etudes_statisti ques/AT_2016/Risque\%20AT\%202016\%20suivant\%201a\%20NAF.pdf (дата обращения: 04.04.2019).

${ }^{5}$ ILOSTAT Database. URL:

http://www.ilo.org/ilostat/faces/home/statisticaldata?_afrLoop=680869279925113\&_adf.ctrl-state=w7otyfthy_4 (дата обращения 04.04.2019).

${ }^{6}$ Сайт Tilastokeskus: URL:https://tilastokeskus.fi/til/ttap/2016/ttap_2016_2018-11-30_tie_001_fi.html (дата обращения: 04.04.2019).
} 
производстве в Германии и во Франции включают данные о производственных травмах с потерей трудоспособности сроком на 4 дня и более, в Финляндии и России - с потерей трудоспособности на 1 рабочий день и более.

Известно, что снижение уровня травматизма на предприятии является следствием значительных вложений в производство: модернизации оборудования, внедрения автоматизированных процессов, существенного улучшения системы охраны труда, в том числе обучения персонала навыкам безопасного проведения работ. Опыт многих стран свидетельствует, что реализация подобных мер, в первую очередь, приводит к снижению частоты травм со смертельным исходом и тяжелых травм, а сокращение несчастных случаев, относящихся к категории легких, происходит более медленными темпами. Например, за период с 1990 по 2016 г. удельный вес погибших в общем числе пострадавших на производстве во Франции снизился с 0,16 до 0,08\%, в Германии - с 0,08 до 0,05\%, в Великобритании - с 0,21 до 0,15\%, в Швеции - с 0,14 до 0,06\%, а в России, напротив, вырос с 1,9\% в 1990 г. до 4,8\% в 2016 г. (International Labour Organization 2019; Социальное положение... 2001; 2004; 2008; 2011; 2017).

В таблице 1 представлены коэффициенты производственного травматизма - общего и со смертельным исходом - и соотношения между ними в России и в государствах-членах Евросоюза в 2016 г. Напомним, что в России регистрируются несчастные случаи на производстве, начиная с первого дня нетрудоспособности. По странам Евросоюза приведены данные только о несчастных случаях на производстве с потерей трудоспособности сроком на 4 дня и более (в том числе и по Финляндии), т. е. показатель общего производственного травматизма в европейских странах должен быть ниже, чем в России.

При анализе таблицы 1 в первую очередь обращает на себя внимание то, что коэффициент общего производственного травматизма в большинстве стран Евросоюза на порядок выше, чем в России, однако по сравнению с Россией частота гибели работников на производстве в европейских странах в несколько раз ниже.

Так, уровень общего производственного травматизма в северных скандинавских странах (Дания, Финляндия, Нидерланды, Швеция, Норвегия) выше, чем в России в 3-14 раз, а со смертельным исходом - ниже в 4-12 раз. Такие же различия в уровнях производственного травматизма по сравнению с Россией наблюдаются в странах центральной Европы (Франция, Германия, Бельгия, Австрия и др.) и в южно-европейских странах, где преимущественно развито сельское хозяйство и промышленное производство (Португалия, Испания, Италия и др.). Эта закономерность прослеживается и при сравнении со многими странами бывшего соцлагеря и СССР. В Словении, Чехии, Польше, Латвии, Литве коэффициент общего травматизма превышает российский показатель в 2-11 раз, а частота травм со смертельным исходом, наоборот, ниже в 1,5-4 раза. Исключение составили Болгария и Румыния.

Исходя из представленных в таблице 1 общих коэффициентов производственного травматизма и травматизма со смертельным исходом, можно рассчитать, что в большинстве стран Евросоюза, за исключением ряда бывших республик СССР и стран соцлагеря, на 1 случай гибели на производстве приходилось от 400-500 до 2000 несчастных случаев (см. 
последний столбец). В России это соотношение выглядит иначе: на 1 травму со смертельным исходом приходится всего 21 травма.

Таблица 1. Коэффициенты общего производственного травматизма и травматизма со смертельным исходом в России и странах Евросоюза в 2016 г., на 1000 работающих

\begin{tabular}{|c|c|c|c|}
\hline \multirow[b]{2}{*}{ Страна } & \multicolumn{2}{|c|}{ Коэффициенты производственного травматизма } & \multirow{2}{*}{$\begin{array}{c}\text { Отношение } \\
\mathrm{K}_{\text {общ. }}^{\text {Пт }} / \mathrm{K}_{\text {смерт.исх }}^{\text {Пт }}\end{array}$} \\
\hline & $\begin{array}{c}\text { общий } \\
\text { Кобщ. }^{\text {пт }}\end{array}$ & $\begin{array}{c}\text { со смертельным исходом } \\
\text { K }_{\text {смерт.исх. }}^{\text {пт }} \\
\end{array}$ & \\
\hline Россия & 1,3 & 0,062 & 21,0 \\
\hline \multicolumn{4}{|c|}{ Скандинавские (Северные) страны } \\
\hline Дания & 17,8 & 0,012 & 1450,1 \\
\hline Финляндия & 16,8 & 0,014 & 1173,2 \\
\hline Нидерланды & 11,3 & 0,005 & 2269,0 \\
\hline Швеция & 7,9 & 0,008 & 1028,5 \\
\hline \multicolumn{4}{|c|}{ Страны центральной Европы и наиболее развитые европейские государства } \\
\hline Франция & 34,6 & 0,027 & 1263,1 \\
\hline Люксембург & 20,6 & 0,063 & 326,2 \\
\hline Германия & 18,4 & 0,009 & 2085,4 \\
\hline Бельгия & 19,9 & 0,018 & 1106,8 \\
\hline Австрия & 16,8 & 0,029 & 577,9 \\
\hline Ирландия & 7,0 & 0,021 & 329,3 \\
\hline Великобритания & 7,2 & 0,008 & 903,3 \\
\hline \multicolumn{4}{|c|}{ Страны южной Европы } \\
\hline Португалия & 29,4 & 0,030 & 978,4 \\
\hline Испания & 28,1 & 0,019 & 1463,1 \\
\hline Италия & 13,0 & 0,021 & 617,4 \\
\hline Мальта & 9,5 & 0,037 & 260,6 \\
\hline Кипр & 5,3 & 0,014 & 380,5 \\
\hline Греция & 1,6 & 0,013 & 121,5 \\
\hline \multicolumn{4}{|c|}{ Страны бывшего СССР и соцлагеря } \\
\hline Словения & 14,3 & 0,017 & 868,4 \\
\hline Эстония & 10,9 & 0,045 & 245,6 \\
\hline Хорватия & 9,6 & 0,024 & 403,6 \\
\hline Чехия & 8,9 & 0,021 & 428,9 \\
\hline Венгрия & 7,1 & 0,021 & 331,3 \\
\hline Польша & 5,3 & 0,015 & 346,5 \\
\hline Словакия & 4,7 & 0,021 & 219,3 \\
\hline Литва & 3,0 & 0,037 & 81,4 \\
\hline Латвия & 2,1 & 0,042 & 48,7 \\
\hline Болгария & 0,8 & 0,030 & 28,0 \\
\hline Румыния & 0,8 & 0,045 & 18,7 \\
\hline
\end{tabular}

Примечание: Коэффищиенты общего производственного травматизма в странах Евросоюза рассчитаны по данным (Eurostat Database 2019).

Источники: (Eurostat Database 2019; Социальное положение... 2017).

В Международной организации труда (МОТ) показатель отношения общего числа травм к числу травм на производстве со смертельным исходом успешно используется при оценке достоверности статистики несчастных случаев на производстве (см. раздел Материалы и методы). Для стран с несовершенной регистрацией несчастных случаев на производстве МОТ рекомендует применять отношения 500:1 и 1000:1.

Вместе с тем, учитывая отличный от европейских стран уровень технического вооружения, производственной безопасности, а также культуры охраны труда и поведения на рабочем месте в России, наряду с отношениями, предложенными МОТ, целесообразно 
изучить собственную историю учета и регистрации производственного травматизма на разных этапах жизни страны и на этой основе вывести показатель соотношения смертельных и несмертельных травм на производстве, характерный для России.

\section{УЧЕТ ПРОИЗВОДСТВЕННОГО ТРАВМАТИЗМА В РОССИИ: КОНЕЦ ХIX - ПЕРВАЯ ТРЕТЬ ХХ ВЕКА}

Изучение производственного травматизма в России началось еще в XIX веке. Первые сведения о пострадавших в результате несчастных случаев на предприятиях появились в 60-е годы XIX века. В дореволюционной России существовала ежегодная статистическая отчетность по промышленности, осуществляемая департаментами Министерства финансов, Горным департаментом Министерства земледелия и государственных имуществ. При этом статистические сведения удовлетворительного качества собирались преимущественно о заводах и фабриках, подлежащих акцизному и горному надзору (Воробьёв 1961).

Данные о пострадавших на производстве в добывающей и горнозаводской промышленности впервые начали публиковаться Горным ученым комитетом в 1859 г. На рисунке 3 представлена динамика коэффициента общего производственного травматизма (А) и травматизма со смертельным исходом (Б) на предприятиях горнозаводской промышленности России в 1877-1907 гг.

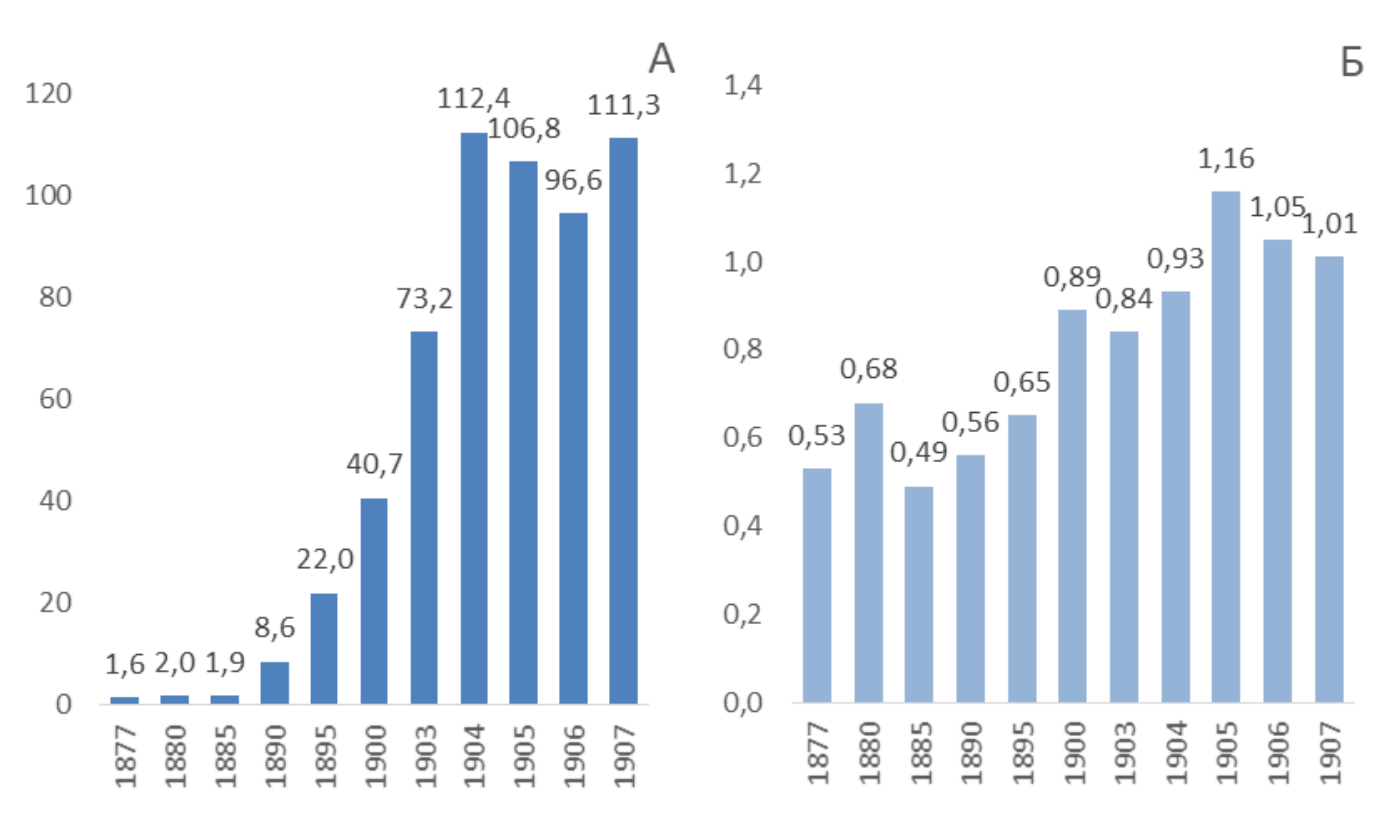

Рисунок 3. Коэффициент общего производственного травматизма (А) и травматизма со смертельным исходом (Б) на предприятиях горнозаводской промышленности России в 1877-1907 гг., на 1000 работников

Примечание: Рассчитано по данным (Сборник статистических сведений... 1888; 1893; 1899; 1903; 1906; 1908; 1910).

Как видно на рисунке 3А, до 1890 г. наблюдались очень низкие коэффициенты общего производственного травматизма. Это связано с тем, что законодательно не была 
оформлена ответственность промышленников за потерю здоровья работниками на предприятиях и травмы легкой и средней тяжести практически не учитывались. Все дела о травмах на производстве рассматривались в судебном порядке, и, чтобы получить вознаграждение за увечье или смерть, работник или члены его семьи должны были доказать вину предпринимателя (Литвинов-Фалинский 1903). В эти годы соотношение общего числа травм и числа травм со смертельным исходом колебалось от 3 до 6 случаев травм на 1 случай гибели на производстве.

В течение 1880-1890 гг. был принят ряд законов, касающихся:

- запрета детского труда;

- запрета ночной работы женщин и подростков;

- регулирования вопросов заработной платы, условий труда и расчета с рабочими;

- установления максимальной продолжительности рабочего дня и др. (Валетов 2007).

В 1882 г. для контроля за исполнением принятых законов и регулирования трудовых отношений была учреждена специальная фабричная инспекция, в функции которой также входил сбор и анализ статистических данных, в ее отчетах содержались сведения о численности предприятий, составе рабочей силы, условиях труда работников, несчастных случаях на производстве, стачках и др.

Фабричное законодательство сыграло значительную роль в улучшении условий труда работников на фабриках и заводах. С развитием трудового законодательства улучшалась и статистика производственного травматизма. В горнозаводской промышленности России в период с 1885 по 1900 г. коэффициенты производственного травматизма всего за 15 лет выросли более чем в 20 раз (с 1,9 до 40,7 на 1000 работников; рисунок 3А). Увеличение показателя травматизма со смертельным исходом также происходило, но значительно медленнее. За эти же 15 лет он вырос только в 1,8 раза (с 0,49 \% в 1885 г. до 0,89 \%о в 1900 г.), что подтверждает лучшую регистрацию травм со смертельным исходом при самом несовершенном учете (рисунок 3Б). Улучшение регистрации легких травм привело к увеличению отношения общего числа несчастных случаев к числу травм со смертельным исходом с 4:1 в 1885 г. до 46:1 к 1900 г.

Знаменательным стал Закон «О вознаграждении потерпевших вследствие несчастных случаев рабочих и служащих, а равно членов их семейств в предприятиях фабрично-заводской, горной и горнозаводской промышленности», принятый в России 2 июня 1903 г., по которому компенсации подлежали все травмы, произошедшие во время работы или в связи с ней, за исключением случаев, вызванных «грубой неосторожностью» или «злым умыслом» (Иванов 1982). Вознаграждение потерпевших проводилось за утрату трудоспособности более чем на три дня. Лечение полностью оплачивалось правлением предприятия.

Закон «О вознаграждении ...» вступил в действие с 1 января 1904 г. Это еще более улучшило регистрацию несчастных случаев. Только за 1904 г. общий коэффициент вырос в 1,5 раза (с 73,2\%о в 1903 г. до 112,4\%о в 1904 г.; рисунок 3А). Последовал рост и отношения общего числа травм к числу травм со смертельным исходом. В 1904 г. на 1 случай гибели на производстве приходилось уже 120 травм, не приведших к гибели работника. 
В последующие годы отношение общего числа несчастных случаев к числу случаев со смертельным исходом колебалось в пределах от 92:1 до 110:1.

Коренные изменения в сторону улучшения регистрации производственного травматизма после принятия Закона 1903 г. произошли не только на предприятиях горной и горнозаводской промышленности, но распространились и на фабрично-заводскую промышленность. По данным фабричных инспекций, производственный травматизм к 1912 г. вырос почти в 3 раза по сравнению с 1901 г. (с 15,9 до 45,8 на 1000 работников; рисунок 4).

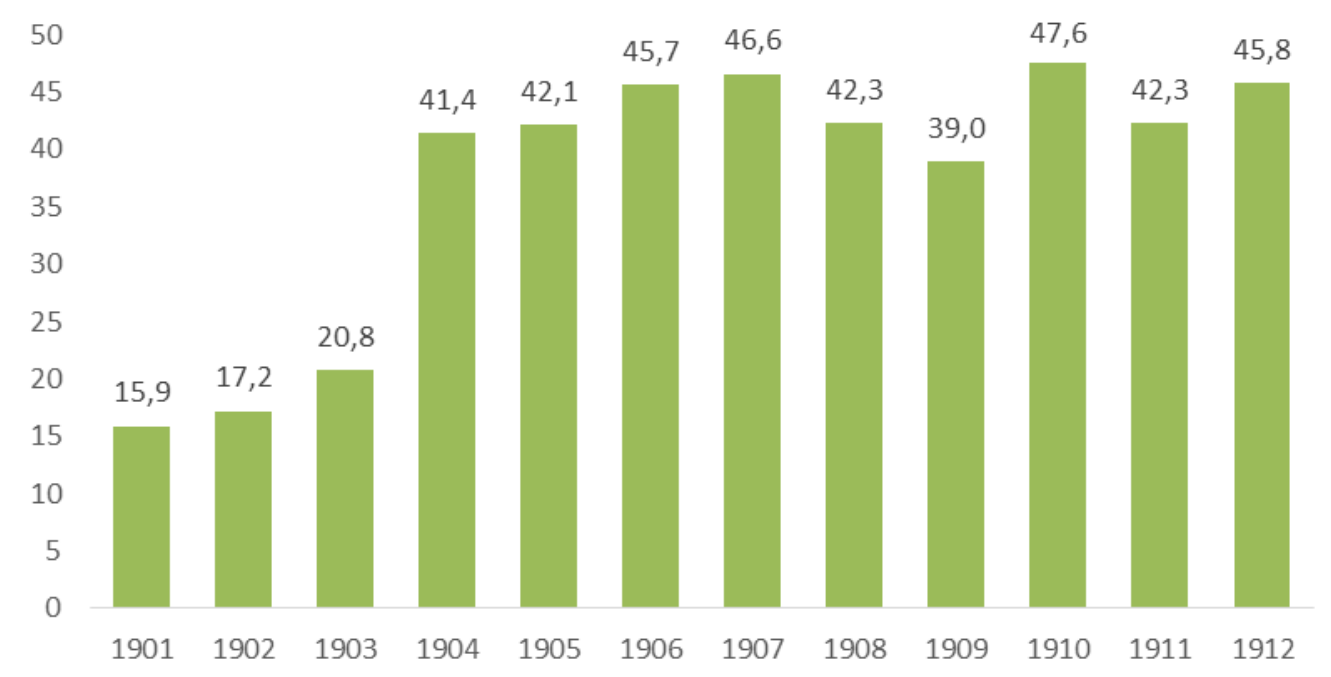

\section{Рисунок 4. Коэффициент общего производственного травматизма на предприятиях фабрично-заводской промышленности России в 1901-1912 гг., на 1000 работников}

Примечание: Рассчитано по данным (Свод отчетов фабричных инспекторов... 1903; 1904; 1907; 1909; 1910; 1915).

Двукратный рост имел место только в течение первого года после принятия Закона (с 20,8 до 41,4 на 1000 работников). Что касается отношения общего числа травм к числу травм со смертельным исходом, то в фабрично-заводской промышленности после изменения законодательства уже в 1904 г. оно выросло до 176:1 и в течение 1905-1912 гг. колебалось в пределах от 179:1 до 214:1.

В России законотворческая деятельность в области социального страхования продолжалась. В 1912 г. был принят свод страховых законов, которые заменили закон 1903 г. По новому законодательству сам предприниматель уже не мог рассчитываться с рабочими за причиненный ущерб здоровью. Для этих целей создавались страховые товарищества, в которых рабочие должны были быть застрахованы в обязательном порядке.

Закон 1912 г. расширил практику страхового обеспечения рабочих по сравнению с законом 1903 г., теперь рабочие страховались также на случай болезни (Иванов 1995). Однако реализация нового закона так и не была завершена в связи с началом Первой мировой войны, а статистические данные за этот период носили разрозненный характер по отдельным страховым товариществам: Петроградскому, Поволжскому, Киевскому, Одесскому и др. В среднем на 1 травму со смертельным исходом в этот период приходилось 215 несмертельных травм (Статистический сборник... 1922). 
После Первой мировой войны, революции и Гражданской войны Наркомтруд СССР разработал ряд Постановлений по сбору и анализу данных о производственном травматизме. По Постановлению №44/321 «О регистрации несчастных случаев» от 25.02.1925 все предприятия, независимо от числа занятых в них рабочих и служащих, обязывались не позднее 48 часов с момента происшествия посылать в инспекции труда извещения обо всех зарегистрированных несчастных случаях, сопровождающихся смертью или утратой трудоспособности на срок один день и более. Виновные в нарушении данного Постановления привлекались инспекцией труда к административной или уголовной ответственности. Столь жесткие меры привели к существенному увеличению регистрируемых показателей частоты несчастных случаев на производстве.

В 1927 г. по данным органов социального страхования Всесоюзного центрального совета профсоюзов в различных отраслях промышленности коэффициент общего производственного травматизма составлял от 89,6 до 419,3 на 1000 работников (таблица 2).

Таблица 2. Коэффициенты общего производственного травматизма и травматизма со смертельным исходом в отдельных отраслях и в целом по промышленности СССР в 1927 г., на 1000 работающих

\begin{tabular}{|c|c|c|c|}
\hline \multirow[b]{2}{*}{ Отрасль промышленности } & \multicolumn{2}{|c|}{ Коэффициенты производственного травматизма } & \multirow{2}{*}{$\begin{array}{c}\text { Отношение } \\
\mathrm{K}_{\text {общ. }}^{\text {Пт }} / \mathrm{K}_{\text {смерт.исх. }}^{\text {пт }}\end{array}$} \\
\hline & $\begin{array}{c}\text { общий } \\
K_{\text {общ. }}^{\text {пт }}\end{array}$ & $\begin{array}{c}\text { со смертельным } \\
\text { исходом } K_{\text {смерт.исх. }}^{\text {пт }}\end{array}$ & \\
\hline Вся промышленность & 212,7 & 0,30 & 709 \\
\hline Металлургия & 307,5 & 0,37 & 831 \\
\hline Каменноугольная & 419,3 & 1,37 & 306 \\
\hline Добыча руд & 318,0 & 0,61 & 521 \\
\hline Бумажная & 127,6 & 0,35 & 365 \\
\hline Швейная & 89,6 & 0,04 & 2240 \\
\hline
\end{tabular}

Источник: (Статистический справочник СССР ... 1929).

Частота несчастных случаев со смертельным исходом на 1000 работников колебалась от 0,04 в швейной отрасли до 1,37 в каменноугольной промышленности. Отношение общего числа травм к числу травм со смертельным исходом в зависимости от отрасли промышленности составляло от 306:1 до 2240:1.

Данные о травматизме в СССР публиковались еще несколько лет - до 1931-32 гг. Затем за длительный период времени в доступной литературе и статистических сборниках информации о производственном травматизме в СССР и РФ не удалось найти.

\section{УЧЕТ ПРОИЗВОДСТВЕННОГО ТРАВМАТИЗМА: 6О-Е ГОДЫ ХХ ВЕКА - НАСТОЯЩЕЕ ВРЕМЯ}

В работе доктора исторических наук, профессора Г.М. Ивановой (2011) приведены данные ЦСУ РСФСР, которые свидетельствуют, что в России в 1965 г. среднегодовая численность рабочих и служащих в промышленности составляла 27 млн человек, при этом было зарегистрировано 676,9 тыс. несчастных случаев на производстве, в том числе 6044 случая со смертельным исходом. Коэффициенты травматизма составили соответственно 21 и 0,19\%о (Иванова 2011). В 1966 г. из 33 млн работников промышленности от несчастных 
случаев на производстве пострадали 632,5 тыс. человек, из них 5744 человек погибли (соответственно 19 и 0,17\%о) (Там же). Из этих данных можно вывести, что в 1965 и 1966 г. на 1 травму со смертельным исходом приходилось соответственно 111 и 110 травм, не приведших к гибели работника.

В течение 1970-80-х годов наблюдалось существенное снижение коэффициентов производственного травматизма (таблица 3 ).

Следует отметить, что уже к 1975 г., по сравнению с серединой 60-х годов, показатель отношения снизился в 2 раза и далее, на протяжении 80 -х годов, колебался в пределах от 40 до 50 производственных травм в расчете на 1 травму со смертельным исходом, что соответствовало ситуации в горнозаводской промышленности до принятия Закона 1903 г., т. е. регресс в учете и регистрации производственного травматизма еще более усугубился.

Таблица 3. Коэффициенты общего производственного травматизма и травматизма со смертельным исходом в СССР в 1975-1988 гг., на 1000 работников

\begin{tabular}{|c|c|c|c|}
\hline \multirow[b]{2}{*}{ Год } & \multicolumn{2}{|c|}{ Коэффициенты производственного травматизма } & \multirow{2}{*}{$\begin{array}{c}\text { Отношение } \\
\mathrm{K}_{\text {общ. }}^{\text {Пт }} / \mathrm{K}_{\text {смерт.исх. }}^{\text {Пт }}\end{array}$} \\
\hline & $\begin{array}{c}\text { общий } \\
\text { Кобщ. }^{\text {пт }} \\
\end{array}$ & $\begin{array}{c}\text { со смертельным исходом } \\
\text { К смерт.исх. }^{\text {пт }} \\
\end{array}$ & \\
\hline 1975 & 9,4 & 0,173 & 54 \\
\hline 1980 & 7,2 & 0,169 & 43 \\
\hline 1985 & 5,6 & 0,133 & 42 \\
\hline 1986 & 5,6 & 0,120 & 47 \\
\hline 1987 & 5,5 & 0,115 & 48 \\
\hline 1988 & 5,4 & 0,115 & 47 \\
\hline
\end{tabular}

Источники: (Труд в СССР... 1989; Социальное развитие... 1991).

Динамика отношения показателей производственного травматизма в странах западной Европы в эти годы имела противоположное направление. Так, например, в Швеции в 1970 г. на 1 травму со смертельным исходом приходилось 448 производственных травм, в 1975 г. -608 , в 1980 г. - 849, в 1985 г. -1068 и так далее 7

В России в 90-е годы XX века и 2000-е годы XXI века тенденция сокрытия производственных травм продолжилась и усилилась, что выразилось в дальнейшем снижении отношения числа всех несчастных случаев на производстве к числу несчастных случаев со смертельным исходом. Если в 1990 г. отношение составляло 51:1, то к 2000 г. оно снизилось до $33: 1$, в 2010 г. - до 24:1, а в 2016 г. достигло 21:1 (Социальное положение... 2001; 2004; 2008; 2011; 2017).

Итак, выполненный исторический анализ показал, что временем наиболее полного учета производственного травматизма в России были пред- и постреволюционный периоды (1904-1932 гг.), когда по стране в целом на один случай гибели на производстве приходилось от 200 до 700 зарегистрированных травм. Если соотнести эти показатели с отношениями, рекомендованными МОТ (500:1 и 1000:1), то при современном техническом

\footnotetext{
${ }^{7}$ Сайт Arbetsmiljöverket: URL: https://www.av.se/arbetsmiljoarbete-och-inspektioner/arbetsmiljostatistik-officiellarbetsskadestatstik/officiell-arbetsskadestatistik/ (дата обращения 27.08.2018).
} 
уровне и безопасности производств они вполне сопоставимы, что позволяет их применить для оценки вероятного общего числа пострадавших на производстве в России.

Итак, в 2016 г. в России по данным Роструда (наиболее полные данные о числе травм со смертельным исходом) на производстве погибло 2072 работника (Министерство труда... 2017). Если принять за гипотезу, что на 1 травму со смертельным исходом приходится от 500 до 1000 несчастных случаев, то вероятное общее количество работников, получивших травмы, в 2016 г. могло составить от 1,0 до 2,1 млн человек, что многократно превышает данные ФСС о 39781 несчастных случаях, зарегистрированных в этом году (Министерство труда... 2017).

Особо подчеркнем, что приведенная оценка базируется только на официально зарегистрированном числе погибших на производстве. По данным некоторых авторов, в отдельных случаях практика сокрытия несчастных случаев на производстве распространяется и на травмы со смертельным исходом, что наиболее характерно в отношении мигрантов на строительных объектах, производственных площадках, при дорожно-транспортных происшествиях (Кузнецов 2005; Волков 2006).

Говоря о сокрытии несчастных случаев на производстве в России, необходимо пояснить причины этого явления. В современных экономических условиях на сокрытие производственной травмы могут быть мотивированы не только работодатели, но и работники. Для работодателя рост числа зарегистрированных травм на предприятии в соответствии со ст. 17 и 22 Федерального закона от 24.07.1998 №125-Ф3 «Об обязательном социальном страховании от несчастных случаев на производстве и профессиональных заболеваний» и действующей системой скидок и надбавок к тарифам на обязательное социальное страхование от несчастных случаев на производстве и профессиональных заболеваний приведет к увеличению отчислений в ФСС.

Кроме того, официальное расследование производственной травмы на предприятии может повлечь за собой дополнительные проверки по охране труда со стороны контролирующих органов, а поскольку на большинстве предприятий имеются нарушения, то вслед за проверкой могут последовать значимые штрафные санкции и даже приостановление деятельности на срок до 90 суток. В настоящее время штрафы за нарушение государственных требований охраны труда, допуск к работе без прохождения предварительных и периодических медицинских осмотров, нарушение порядка проведения СОУТ и др. составляет для юридических лиц от 50 тыс. до 150 тыс. рублей. При этом штрафные санкции за различные виды нарушений суммируются. На фоне высоких штрафных санкций за нарушения в области охраны труда штраф за сокрытие производственной травмы составляет лишь от 5 до 10 тыс. рублей ${ }^{8}$.

Существуют экономические причины, способные мотивировать самого работника не регистрировать травму. Так, сохраняется большое количество предприятий и организаций, где значительная часть заработной платы выдается в «конвертах». В случае

\footnotetext{
${ }^{8}$ Ст. 5.27 и 5.27.1 Кодекса Российской Федерации об административных правонарушениях от 30.12 .01 №195-Ф3.
} 
производственной травмы больничный лист оплачивается, исходя из официальной заработной платы, которая существенно ниже фактического заработка. Работнику выгодно не оформлять травму как производственную, если работодатель обещает компенсировать понесенный ущерб. При этом разница в оплате больничных листов по производственной и бытовой травмам в настоящее время практически отсутствует.

Кроме того, регистрация несчастного случая может повлечь напряжение в отношениях работника с руководством предприятия, что нежелательно в условиях сложной ситуации на рынке труда. Поэтому для работника в случае легкой травмы экономически выгодно не регистрировать ее, если работодатель предлагает оплатить затраты на лечение и компенсировать утраченный заработок.

Дополнительные предпосылки к сокрытию производственных травм создает низкая правовая грамотность значительной части трудящихся страны. Работник соглашается на предложение работодателя не регистрировать производственную травму, не обладая информацией о положенных ему компенсациях по обязательному социальному страхованию в случаях, если травма повлечет стойкую утрату трудоспособности, а также других гарантиях, предусмотренных законодательством.

\section{ЗАКЛЮЧЕНИЕ}

В настоящее время в России идет процесс модернизации системы управления охраной труда на государственном уровне. Его целью является переход от ранее действовавшей неэффективной системы, ориентированной на доплаты за работу во вредных, опасных и тяжелых условиях труда, а также выплаты за утраченное здоровье и на медико-социальную помощь работникам, пострадавшим от производственных травм или профессиональных заболеваний, к современной системе, основанной на оценке профессиональных рисков.

Превентивные подходы к сохранению здоровья работающих посредством постоянного улучшения условий труда, безопасности производственных процессов, формирования культуры безопасного поведения персонала и особенно важны для России, где смертность мужского населения трудоспособного возраста чрезвычайно велика. Именно поэтому новая система управления охраной труда может послужить важным компонентом среди мер, предусмотренных Концепцией демографической политики в России по сокращению смертности в трудоспособном возрасте.

В условиях модернизации системы управления охраной труда важнейшее значение имеет информационная составляющая, т. е. данные, которые служат базой для оценки профессионального риска. Существуют два официальных статистических показателя, характеризующих состояние здоровья работающего населения: производственный травматизм и профессиональная заболеваемость. Неудовлетворительная, по мнению специалистов, регистрация профессиональных заболеваний (Измеров 2013; Атаманчук, Кабанова 2015) и массовое сокрытие несчастных случаев, которому в значительной степени способствовали изменения в трудовом законодательстве двух последних десятилетий, приводят к полному искажению реального положения на предприятиях, а также в масштабе отраслей и страны в целом, и соответственно становятся серьезным препятствием для 
выработки адекватной государственной политики в области охраны труда и сохранения здоровья работающего населения, а также могут дискредитировать саму внедряемую систему, основанную на оценке профессиональных рисков, принятую в большинстве развитых стран мира.

\section{ЛИТЕРАТУРА}

Атаманчук А.А., Кабанова Т.Г. (2015). Системные проблемы выявления профессиональных заболеваний в Российской Федерации. Медицина труда $u$ промышленная экология, 9, 25-28.

Валетов Т.Я. (2007). Фабричное законодательство в России до Октябрьской революции. В Л.И. Бородкина (Ред.), Экономическая история. Обозрение. Выпуск 13 (с. 34-44). М.: Изд-во МГУ. (Труды исторического факультета МГУ: Вып. 39).

Вишневский А.Г. (Ред.) (2017). Смертность от внешних причин в России с серединь ХХ века. М.: Изд. дом ГУ ВШЭ. 448 с.

Волков Ю. И. (2006). "Непрозрачный" травматизм. Охрана труда и сочииальное страхование, 6, 3-7.

Воробьев Н.Я. (1961). Очерки по истории промылиенной статистики в дореволющионной России и в СССР. М.: Госстатиздат. 133 с.

ГТПДТ и Бюро МОТ для стран Восточной Европы и Центральной Азии (2010). Страхование от несчастных случаев на производстве и профессиональных заболеваний. URL: https://www.ilo.org/wcmsp5/groups/public/---europe/---ro-geneva/--sro-moscow/documents/publication/wcms_312468.pdf

Евстигнеева Н.А. (2016). Статистика условий труда после введения процедуры специальной оценки условий труда. Международный журнал прикладных и фундаментальных исследований, 8-5, 673-677.

Иванов Л.М. (1982). Закон 1903 г. о вознаграждении увечных рабочих и его практическое применение. В Рабочее движение в России в период империализма (с. 88-126). М.

Иванов Л.М. (1995). Страховой закон 1912 года и его практическое применение. Отечественная история, 5, 73-87.

Иванова Г.М. Проблемы советской модернизации и социальные риски во второй половине 1950-х - начале 1970-х годов (2011). В В.М. Лавров (Ред.), Русский исторический сборник. Т.3 (с.164-188). М.: Кучково поле.

Измеров Н.Ф. (2013). Актуализация вопросов профессиональной заболеваемости. Здравоохранение Российской Федерации, 2, 14-17.

Измеров Н.Ф., Тихонова Г.И., Чуранова А.Н., Горчакова Т.Ю. (2013). Условия, охрана труда и производственный травматизм в России. Здравоохранение Российской Федеращии, 1, 3-7

Кузнецов Г. (2005). Реальный травматизм и официальная отчетность. Охрана труда $и$ сочиальная безопасность, 10, 43-47.

Литвинов-Фалинский В.П. (1903). Ответственность предпринимателей за увечья и смерть рабочих по действующим в России законам. СПб.: Типография А.С. Суворина. 
Министерство труда и социальной защиты Российской Федерации (2017). Доклад о результатах мониторинга условий и охраны труда в Российской Федерации в 2016 году. URL: http://eisot.rosmintrud.ru/attachments/article/47/results_2016.doc

Основные показатели первичной инвалидности взрослого населения в Российской Федерации (2016). Статистический сборник. М: ФБ МСЭ. 263 с.

Роспотребнадзор (2017). О состоянии санитарно-эпидемиологического благополучия населения в Российской Федерации в 2016 году.

URL:https://rospotrebnadzor.ru/documents/details.php?ELEMENT_ID=8345

Росстат (2017). Демографический ежегодник России 2017. URL:

http://www.gks.ru/wps/wcm/connect/rosstat_main/rosstat/ru/statistics/publications/catalog/do c_1137674209312

Русак О. (2006). Неоправданный оптимизм. Охрана труда и социальное страхование, 6 , 12-15.

Сборник статистических сведений о горнозаводской промышленности России в 1886 году (1888). Петроград: Горный учен. ком. 340 с.

Сборник статистических сведений о горнозаводской промышленности России в 1891 году (1893). Петроград: Горный учен. ком. 311 с.

Сборник статистических сведений о горнозаводской промышленности России в 1896 году (1899). Петроград: Горный учен. ком. 468 с.

Сборник статистических сведений о горнозаводской промышленности России в 1900 году (1903). Петроград: Горный учен. ком. 700 с.

Сборник статистических сведений о горнозаводской промышленности России в 1903 году (1906). Петроград: Горный учен. ком. 632 с.

Сборник статистических сведений о горнозаводской промышленности России в 1905 году (1908). Петроград: Горный учен. ком. 630 с.

Сборник статистических сведений о горнозаводской промышленности России в 1907 году (1910). Петроград: Горный учен. ком. 340 с.

Свод отчетов фабричных инспекторов за 1901 г. (1903). СПб. 202 с.

Свод отчетов фабричных инспекторов за 1902 г. (1904). СПб. 200 с.

Свод отчетов фабричных инспекторов за 1904 г. (1907). СПб. 212 с.

Свод отчетов фабричных инспекторов за 1907 г. (1909). СПб. 156 с.

Свод отчетов фабричных инспекторов за 1909 г. (1910). СПб. 195 с.

Свод отчетов фабричных инспекторов за 1914 г. (1915). СПб. 291 с.

Социальное положение и уровень жизни населения России. Стат.сб. (2001). Госкомстат

России. М. 463 с.

Социальное положение и уровень жизни населения России. 2004. Стат.сб. (2004). Росстат. M. 509 c.

Социальное положение и уровень жизни населения России. 2008. Стат.сб. (2008). Росстат. M. 502 c.

Социальное положение и уровень жизни населения России. 2011. Стат.сб. (2011). Росстат. M. 527 c. 
Социальное положение и уровень жизни населения России. 2017. Стат. сб. (2017). Росстат. M. 332 c.

Социальное развитие СССР. 1989 г. Стат. сб. (1991). Госкомстат СССР. М.: Финансы и статистика. $416 \mathrm{c.}$

СССР в цифрах. Стат. сб. (1935). М.: ЦУНХУ Госплана СССР - В/О «Союзоргучет». 206 с.

Статистический сборник за 1913-1917 гг. (1922). Труды центрального статистического управления. Том VII. Выпуск 2. М. 307 с.

Статистический справочник СССР за 1928 г. (1929). Статистическое издательство ЦСУ CCCP. M. 958 c.

Тихонова Г.И., Горчакова Т.Ю. (2018). Смертность населения трудоспособного возраста: международные сравнения. Материалы XII Всероссийского форума «Здоровье нации - основа процветания России» (с.44-49). М.: Общероссийская общественная организация «Лига здоровья нации».

Труд в СССР. 1988. Стат. сб. (1989). Госкомстат СССР. М.: Финансы и статистика. 304 с.

Труд и занятость в России. 2017. Стат. сб. (2017). Росстат. М.: 261 с.

Eurostat Database (2019). Health and safety at work. Retrieved April 04, 2019 from http://ec.europa.eu/eurostat/data/database.

Hämäläinen P., Saarela K. L., Takala J. (2009). Global trend according to estimated number of occupational accidents and fatal work-related diseases at region and country level. Journal of Safety Research, Volume 40, Issue 2, 125-139.

International Labour Organization (2019). ILOSTAT databases. Retrieved April 04, 2019 from http://www.ilo.org/ilostat/faces/home/statisticaldata?_afrLoop=680869279925113\&_adf.ctrlstate=w7otyfthy_4. 


\title{
LONG-TERM ANALYSIS OF THE FEATURES OF OCCUPATIONAL INJURY RECORDING AND REPORTING IN RUSSIA
}

\author{
GALINA TikHONOVA, ANASTASIA CHURANOVA
}

\begin{abstract}
External causes are one of the leading classes in the structure of excess mortality of working-age men. In Russia, the numbers both of hazardous jobs and fatalities at work due to accidents are high. Occupational injuries (OI) are differentiated into total and fatal OI.

There has been a steady decrease in the frequency of occupational injuries in despite deteriorating working conditions for several decades. The ratio of OI in 2015 was 1,3\% in Russia and 7,6-29,5\% in most European countries. Based on the experience of developed countries, the International Labor Organization recommends using the ratio of total OI to 1 fatal OI, equal to 500-1000:1, to estimate the probable number of total OI in countries with poor recording. The feasibility of using this parameter for Russia was confirmed by historical analysis. A ratio close to modern European indicators was reached in Russia in 1904-1930. In 2016, it was only 21:1. Taking into account the recommended ratio, the number of people injured at work could be 1.0-2.1 million, compared to the 39.9 thousand officially registered.
\end{abstract}

The Demographic Policy Concept in Russia provides for the reduction of working-age mortality by improving working conditions and labour protection, including the implementation of a new labour protection management system based on the assessment of occupational risks. OI is one of the two official statistical indicators of workers' health. Mass concealment of industrial accidents hinders the creation of an adequate database and sound administrative decision-making.

Key words: external causes of mortality, occupational injuries.

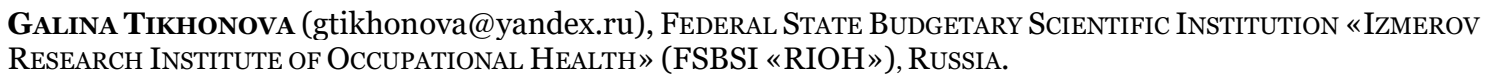

Anastasia Churanova (nastja_30o6@mail.ru), Federal State Budgetary SCIENTIFIC Institution «IZMEROv RESEARCH INSTITUTE OF OCCUPATIONAL HEALTH» (FSBSI «RIOH»), RUSSIA.

DATE RECEIVED : FEBRUARY 2019.

\section{REFERENCES}

Atamantchuk A.A., Kabanova T.G. (2015). System problems of occupational diseases revealing in the Russian Federation. Medicina truda i promyshlennaya ekologiya [Occupational medicine and industrial ecology], 9, 25-28. (In Russ.)

Eurostat Database (2019). Health and safety at work. Retrieved April 04, 2019 from http://ec.europa.eu/eurostat/data/database .

Evstigneeva N.A. (2016). Working conditions statistics after introduction of special assessment by working conditions. International Journal of Applied and Basic Research, 8-5, 673-677. (In Russ.)

Hämäläinen P., Saarela K. L., Takala J. (2009). Global trend according to estimated number of occupational accidents and fatal work-related diseases at region and country level. Journal of Safety Research, Volume 40, Issue 2, 125-139. 
ILO Subregional Office for Eastern Europe and Central Asia (2010). Straxovanie ot neschastny`x sluchaev na proizvodstve i professional`ny`x zabolevanij [Insurance against industrial accidents and occupational diseases].

URL:https://www.ilo.org/wcmsp5/groups/public/---europe/---ro-geneva/---sromoscow/documents/publication/wcms_312468.pdf

International Labour Organization (2019). ILOSTAT databases. Retrieved April 4, 2019 from http://www.ilo.org/ilostat/faces/home/statisticaldata?_afrLoop=680869279925113\&_adf.ctrlstate=w7otyfthy_4.

Ivanov L.M. (1982). Zakon 1903 g. o voznagrazhdenii uvechny`x rabochix i ego prakticheskoe primenenie [The law of 1903 on compensation of disabled workers and its practical application]. V Rabochee dvizhenie v Rossii v period imperializma [Labor movement in Russia in the period of imperialism] (p. 88-126). Moscow. (In Russ.)

Ivanov L.M. (1995). Straxovoj zakon 1912 goda i ego prakticheskoe primenenie [Insurance law of 1912 and its practical application]. Otechestvennaya istoriya, 5, 73-87. (In Russ.)

Ivanova G.M. (2011). Problemy` sovetskoj modernizacii i social`ny`e riski vo vtoroj polovine 1950-x nachale 1970-x godov [Problems of Soviet modernization and social risks in the second half of the 1950s and early 1970s]. In V.M. Lavrov (Ed.), Russkij istoricheskij sbornik [Russian historical collection. T.3 (p.164-188). Moscow: Kuchkovo pole. (In Russ.)

Izmerov N.F. (2013). Aktualizaciya voprosov professional noj zabolevaemosti. [Updating occupational morbidity issues] Zdravooxranenie Rossijskoj Federacii, 2, 14-17. (In Russ.)

Izmerov N.F., Tikhonova G.I., Churanova A.N., Gorchakova T.Yu. (2013). The conditions, occupational safety and on-the-job traumatism in Russia. Zdravoohranenie Rossijskoj Federacii [Healthcare of the Russian Federation], 1, 3-7. (In Russ.)

Kuzneczov G. (2005). Real`ny’j travmatizm i oficial’naya otchetnost` [Real injuries and oficial reporting]. Oxrana truda i social naya bezopasnost', 10, 43-47. (In Russ.)

Litvinov-Falinskij V.P. (1903). Otvetstvennost` predprinimatelej za uvech ya i smert rabochix po dejstvuyushhim $v$ Rossii zakonam [Responsibility of entrepreneurs for injury and death of workers under the laws in force in Russia]. Sankt-Peterburg: Tipografiya A.S. Suvorina. 95 p. (In Russ.)

Ministerstvo truda i social`noj zashhity`Rossijskoj Federacii (2017). Doklad o rezul tatax monitoringa uslovij i oxrany` truda v Rossijskoj Federacii v 2016 godu. [Report on the results of monitoring of the labour conditions and labor protection in the Russian Federation in 2016] URL: http://eisot.rosmintrud.ru/attachments/article/47/results_2016.doc

Osnovny`e pokazateli pervichnoj invalidnosti vzroslogo naseleniya v Rossijskoj Federacii (2016). [Main indicators of primary disability of the adult population in the Russian Federation]. Stat. handbook. Moscow: FB MSE'. 263 p.

Rospotrebnadzor (2017). O sostoyanii sanitarno-e 'pidemiologicheskogo blagopoluchiya naseleniya v Rossijskoj Federacii v 2016 godu [On the state of sanitary and epidemiological welfare in the Russian Federation in 2016].

URL:https://rospotrebnadzor.ru/documents/details.php?ELEMENT_ID=8345

Rosstat (2017). The Demographic Yearbook of Russia. URL:

http://www.gks.ru/wps/wcm/connect/rosstat_main/rosstat/ru/statistics/publications/catalog/do c_1137674209312 (In Russ.)

Rusak O. (2006). Neopravdanny`j optimizm [Unjustified optimism]. Oxrana truda $i$ social`noe straxovanie, 6, 12-15. (In Russ.) 
Sbornik statisticheskix svedenij o gornozavodskoj promy`shlennosti Rossii v 1886 godu. (1888). [Collection of statistical information about the mining industry of Russia in 1886]. (In Russ.)

Sbornik statisticheskix svedenij o gornozavodskoj promy`shlennosti Rossii v 1891 godu.

[Collection of statistical information about the mining industry of Russia in 1891]. (1893).

Petrograd: Gorny`j uchen. kom. 311 p. Petrograd: Gorny`j uchen. kom. 340 p. (In Russ.)

Sbornik statisticheskix svedenij o gornozavodskoj promy`shlennosti Rossii v 1896 godu.

[Collection of statistical information about the mining industry of Russia in 1896]. (1899).

Petrograd: Gorny`j uchen. kom. 468 p. (In Russ.)

Sbornik statisticheskix svedenij o gornozavodskoj promy`shlennosti Rossii v 1900 godu

[Collection of statistical information about the mining industry of Russia in 1900]. (1903).

Petrograd: Gorny`j uchen. kom. 700 p. (In Russ.)

Sbornik statisticheskix svedenij o gornozavodskoj promy`shlennosti Rossii v 1903 godu

[Collection of statistical information about the mining industry of Russia in 1903]. (1906).

Petrograd: Gorny`j uchen. kom. 632 p. (In Russ.)

Sbornik statisticheskix svedenij o gornozavodskoj promy`shlennosti Rossii v 1905 godu

[Collection of statistical information about the mining industry of Russia in 1905]. (1908).

Petrograd: Gorny`j uchen. kom. 630 p. (In Russ.)

Sbornik statisticheskix svedenij o gornozavodskoj promy`shlennosti Rossii v 1907 godu

[Collection of statistical information about the mining industry of Russia in 1907]. (1910).

Petrograd: Gorny`j uchen. kom. 340 p. (In Russ.)

Social `noe polozhenie i uroven`zhizni naseleniya Rossii. 2001 [Social situation and standard of living of the population in Russia. 2001]. Stat.handbook (2001). Goskomstat Rossii.

Moscow. 463 p.

Social’noe polozhenie i uroven`zhizni naseleniya Rossii. 2004[Social situation and standard of living of the population in Russia.2001] . Stat.handbook (2004). Rosstat. Moscow. 509 p.

Social`noe polozhenie i uroven`zhizni naseleniya Rossii. 2008 [Social situation and standard of living of the population in Russia.2001]. Stat.handbook (2008). Rosstat. Moscow. 502 p.

Social’noe polozhenie i uroven`zhizni naseleniya Rossii. 2011[Social situation and standard of living of the population in Russia.2001]. Stat.handbook (2011). Rosstat. Moscow. 527 p.

Social’noe polozhenie i uroven`zhizni naseleniya Rossii. 2017 [Social situation and standard of living of the population in Russia.2001]. Stat.handbook (2017). Rosstat. Moscow. 332 p.

Social noe razvitie SSSR. 1989 g. Stat.handbook (1991). Goskomstat SSSR, Informacionnoizdatel 'skij otdel. Moscow: Finansy`i statistika. 416 p. (In Russ.)

SSSR v cifrax. [USSR in figures]. Stat.handbook (1935). CUNXU Gosplana SSSR - V/O «Soyuzorguchet». Moscow. 206 p. (In Russ.)

Statisticheskij sbornik za 1913-1917 gg. [Stat. handbook for 1913-1917]. (1922). Trudy central`nogo statisticheskogo upravleniya. Tom VII, 2. Moscow. 307 p. (In Russ.)

Statisticheskij spravochnik SSSR za 1928 g. [USSR Stat. handbook for 1928] (1929). Statisticheskoe izdatel`stvo CzSU SSSR. Moscow. 958 p. (In Russ.)

Svod otchetov fabrichny`x inspektorov za $1901 \mathrm{~g}$. [Summary of factory inspectors reports for 1901] (1903). Sankt-Peterburg. 202 p. (In Russ.)

Svod otchetov fabrichny`x inspektorov za $1902 \mathrm{~g}$. [Summary of factory inspectors reports for 1902] (1904). Sankt-Peterburg. 200 p. 
Svod otchetov fabrichny`x inspektorov za $1904 \mathrm{~g}$. [Summary of factory inspectors reports for 1904] (1907). Sankt-Peterburg. 212 p.

Svod otchetov fabrichny`x inspektorov za $1907 \mathrm{~g}$. [Summary of factory inspectors reports for 1907] (1909). Sankt-Peterburg. 156 p.

Svod otchetov fabrichny`x inspektorov za $1909 \mathrm{~g}$. [Summary of factory inspectors reports for 1909] (1910). Sankt-Peterburg. 195 p.

Svod otchetov fabrichny`x inspektorov za $1914 \mathrm{~g}$. [Summary of factory inspectors reports for 1914] (1915). Sankt-Peterburg. 291 p.

Tikhonova G.I., Gorchakova T.Yu. (2018). Smertnost` naseleniya trudosposobnogo vozrasta: mezhdunarodny'e sravneniya [Mortality of the working age population: international comparisons]. Materialy`XII Vserossijskogo foruma «Zdorov`e nacii - osnova proczvetaniya Rossii» (p. 44-49). Moscow: Obshherossijskaya obshhestvennaya organizaciya «LIGA ZDOROV'Ya NACII». (In Russ.)

Trud i zanyatost` v Rossii. 2017 [Labor and employment in Russia. 2017]. Stat.handbook (2017). Rosstat. M.: 261 p. (In Russ.)

Trud v SSSR. 1988. [Labor in the USSR]. Stat.handbook (1989). Goskomstat SSSR. Moscow: Finansy`i statistika. 304 p. (In Russ.)

Valetov T.Ya. (2007). Labour Legislation in Russia before the October Revolution. E`konomicheskaya istoriya. Obozrenie [Economic history. Review]. Issue 13. In L.I. Borodkin (Ed). Trudy istoricheskogo fakul teta MGU [Proceedings of the Faculty of History of Moscow State University], Vol. 39, (p. 34-44). Moscow, MGU. (In Russ.)

Vishnevsky A.G. (Ed.). (2017). Mortality from external causes in Russia since the middle of the $X X$ century. Moscow: HSE Publishing House (In Russ.)

Volkov Yu.I. (2006). "Neprozrachny`j" travmatizm [“Opaque” injuries]. Oxrana truda $i$ social noe straxovanie, 6, 3-7. (In Russ.)

Vorob'yev N.Ya. (1961). Ocherki po istorii promy`shlennoj statistiki v dorevolyucionnoj Rossii $i$ $v$ SSSR [Essays on the history of industrial statistics in pre-revolutionary Russia and the Soviet Union]. Moscow: Gosstatizdat. 133 p. (In Russ.) 